\title{
The Relationship of Finger Length Ratios (2D:4D) with Quantitative, Verbal Talent and Anthropometric Parameters
}

\author{
La Relación de las Proporciones de La Longitud Del Dedo (2D: 4D) con \\ El Parámetro Cuantitativo, Talento Verbal Y Parámetros Antropométricos
}

Raciha Sinem Balci; Ahmet Kürsad Acikgöz; Pinar Göker \& Memduha Gülhal Bozkir

BALCI, R. S.; AÇIKGÖZ, A. K.; GÖKER, P. \& BOZKIR, M. G. The relationship of finger length ratios (2D:4D) with quantitative, verbal talent and anthropometric parameters. Int. J. Morphol., 36(1):310-318, 2018.

SUMMARY: The aim of this study were to investigate the relationship between 2D:4D finger length ratios (the ratio of the second finger length to the fourth finger length) of students from verbal and quantitative weighted fields, and to determine the correlation of these ratios with some anthropometric measurements. For this purpose; hand length, hand width, lengths of second and fourth finger and waist, hip and neck circumferences were taken from totally 398 (199 female, 199 male) students aged 17-25 years by using millimetric callipers and non-elastic standard measuring tape. Demographic data were also taken. Moreover, Body Mass Index (BMI) and 2D:4D finger length ratios of the study group were also calculated. When we investigated the 2D:4D ratios for right, left and dominant hands among verbal and quantitative talented individuals in female students, there were statistically significant differences for right and dominant hand ( $\mathrm{p}=0.032 ; \mathrm{p}=0.042$, respectively). On the other hand, there was no difference for left hand in female participants ( $\mathrm{p}>0.05)$. Furthermore, there were positive correlations with $2 \mathrm{D}: 4 \mathrm{D}$ and weight $(\mathrm{r}=0.38, \mathrm{p}<0.001)$, BMI $(\mathrm{r}=0.34, \mathrm{p}=0.01)$ of the male students in verballyweighted field and with hip and waist circumferences in male students in quantitatively-weighted field $(r=0.30 ; p=0.002 ; \mathrm{r}=0.41, \mathrm{p}<0.001)$. In male students in quantitatively-weighted fields, there was a weak and positive correlation with 2D:4D finger length ratios and neck circumferences on the left hand, and this relationship was statistically significant $(\mathrm{r}=0.21 ; \mathrm{p}=0.032)$. And also, there were no statistically significant correlations between anthropometric measurements and 2D:4D ratios among the female students in quantitatively weighted field. Whereas there were positive correlations with 2D:4D finger length ratios and waist circumference in female students in verballyweighted field $(r=0.24, p=0.018)$. We believe that the data obtained in this study will be a guide for career planning goals of persons according to their quantitative and verbal talents.

KEY WORDS: Finger length rates; Quantitative talent; Verbal talent.

\section{INTRODUCTION}

Data of the proportion of the human body is extremely important. These data reveal many details about personal characteristics and abilities. Ability can be defined as accomplishing the same amount of work more efficiently than others when the same work is performed by different people with the same characteristics (Gardner \& Hatch, 1989). Ability is regarded as a hereditary characteristic (McGue \& Bouchard, 1998). Quantitative talent involves behaviours such as using numbers effectively, finding scientific solutions for problems, and identifying and assessing different concepts. Verbal talent is stated as the ability of using communication effectively (Gardner \& Hatch). Very significant studies have been carried out about revealing human-specific abilities in recent years. As a result of many researches it was determined that finger ratios are the same as in prenatal period, and they do not change in forthcoming years (Manning et al., 2004). There is a difference in terms of sex in the ratio of the length of the 2 nd digit (the index finger) and the 4 th digit (the ring finger) (digit ratio, 2D:4D) such that male subjects have lower 2D:4D than female subjects (Fink et al., 2004; Trivers $e t$ al., 2006). It was indicated in many previous researches that 2D:4D ratios are associated with various physiological and behavioural characteristics (Fowkes et al., 1992). There are many studies about the relationship between Body-Mass Index and anthropometric measurements like neck circumference, waist circumference, etc. Some researchers believe that finger ratios might be the symptoms of some diseases when considered together with the relationship between neck circumference and myocardial infarction (Fink 
et al., 2006). In this sense, the ratio of second finger length to fourth finger length (2D:4D) is an important physical characteristic for determining the levels of sex-related hormonal factors and obtaining information about personal preferences and abilities (Fowkes et al.). 2D:4D ratios are under the influence of exposure level of testosterone/ oestrogen during the prenatal period (Manning et al., 2003). According to previous researches, testosterone is effective on the development of the fourth finger while oestrogen is effective on the development of the second finger (Manning et al., 2000). Consequently, there is a direct proportionality between the second finger length and oestrogen levels also between the fourth finger length and testosterone levels (Manning et al., 1998). 2D:4D finger length ratio values are lower in male population $(<0.98)$ whereas they are higher in female population (>0.98) (Çelik et al., 2010).

The aims of this study were to determine the relationship between 2D:4D finger length ratios and verbal/ quantitative talents and also to compare these ratios with various anthropometric measurements among young males and females.

\section{MATERIAL AND METHOD}

Our study group consisted of 398 students aged between 18-25 years, and was separated into two groups. The first group included 198 students (99 male, 99 female) which were studying in verbal weighted fields and the second group contained 200 students (100 male, 100 female) which were studying in quantitative weighted fields. Informed consent forms were received from the participants before measurements. After collecting information about demographic data, the following measurements were performed:

- Waist circumference: At the level of the midpoint between costae 12 and crista iliaca.

- Hip circumference: At level of the symphisis pubis in the front and the largest level of hip in the back.

- Waist-Hip Ratios

- Neck circumference: At the level of the mid-cervical vertebra and midpoint of the neck in the front.

- Body-Mass Index (BMI): $\mathrm{kg} / \mathrm{m}^{2}$

- Hand Length: Vertical distance from the transverse axis of the outermost point of the radius and ulnae processus. styloideus and the most distal point of the third finger (Fig. 1: Distance from $\mathrm{E}$ to $\mathrm{F}$ ).

- Hand Width: The transverse distance at the level of the outermost point of second and fifth metacarpophalangeal joint (Fig. 1: Distance from $\mathrm{G}$ to $\mathrm{H}$ ).
- Second Finger Length: Distance from the midpoint of the second metacarpophalangeal joint and the most distal point of the second finger (Fig. 1: Distance from A to B).

- Fourth Finger Length: Distance from the midpoint of the fourth metacarpophalangeal joint and the most distal point of the fourth finger (Fig.1: Distance from C to D).

2D: 4D Finger Length Ratios: Ratio of the second finger length to the fourth finger length (Fig. 1: Ratio of A-B/CD).

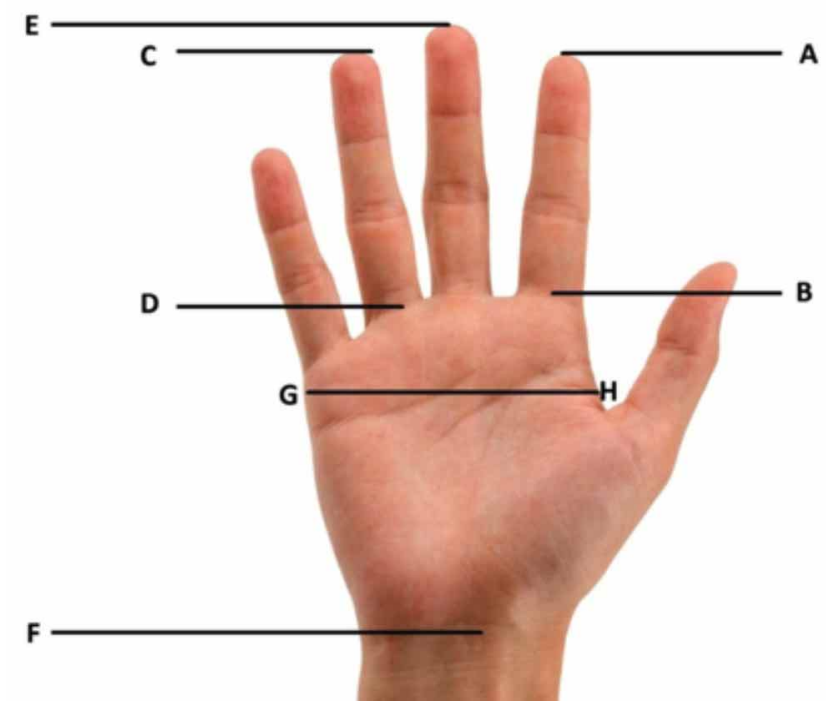

Fig. 1. Hand Measurements: A-B: Second Finger Length, C-D: Fourth Finger Length, E-F: Hand Length, G-H: Hand Width.

Millimetric sliding calliper, nonelastic tape measure, and digital weighing scale were used for anthropometric measurements in this study. The 'Statistical Package for Social Sciences for Windows 20.0' (SPSS 20inc) was used for data analysis. The Chi-square Test was used for categorical variables analysis, the Student-t Test was used for independent variables, and the Mann-Whitney U-test was used for dependent variables in the comparisons of groups. Graphics were used for statistically different variables. The Pearson Correlation Test was used for the relationship between 2D:4D finger ratios and the anthropometric measurements. The level of significance was taken as $\mathrm{p}<0,05$.

\section{RESULTS}

199 male and 199 female students participated in this study. This ratio was suitable in terms of statistics. The distribution of the study group is shown in Table I.

As one of the main purpose of this study, we investigated the 2D:4D ratios of the participants among 


\begin{tabular}{lll}
\hline Variable & & $\mathrm{n}(\%)$ \\
\hline \multirow{2}{*}{ Group } & Verbal & $198(49.7)$ \\
& Quantitative & $200(50.3)$ \\
Sex & Male & $199(50.0)$ \\
\multirow{2}{*}{ Dominant hand } & Female & $199(50.0)$ \\
& Left & $48(12.1)$ \\
& Right & $350(87.9)$ \\
\hline
\end{tabular}

Table I. Distribution of the participants.

verbally and quantitatively talented individuals, and it was found that there were statistically significant differences for the right and dominant hands $(\mathrm{p}=0.032 ; \mathrm{p}=0.042$, respectively); however, there were no statistically significant differences for the left hand ( $p>0.05)$ (Table II).

The 2D:4D ratios of the males were found to be 0.991 and $0.999 \mathrm{~mm}$ for the right and left hands, respectively. Also, it was found to be 1.010 (right hand) and $1.006 \mathrm{~mm}$ (left hand) for females. These results were found to be statistically significant (Table III). There were statistically significant differences among males when we analysed the variable distribution for the groups in terms of right-left hand length, hip and waist circumferences $(p=0.002 ; p<0.001 ; p=0.05$; $\mathrm{p}=0.05$, respectively). The waist and hip circumferences were higher in quantitatively weighted concepts in male students when compared with the verbally weighted concept groups. Also, the right and left hand lengths were found to be lower (Table IV).

When we investigated the variable distribution among females in groups, there were statistically significant differences between the quantitatively and verbally weighted concepts in female student groups in terms of 2D:4D finger length ratios at the right dominant hand $(\mathrm{p}=0.024 ; \mathrm{p}=0.05$, respectively). There were no statistically differences at the left hand for 2D:4D ratios ( $p>0.05$, Table V, Fig. 2).

Table II. Total distribution of 2D:4D ratios for groups

\begin{tabular}{llll}
\hline \multicolumn{1}{c}{ Variables } & Verbal & Groups & \\
& $\begin{array}{l}\text { Ave. } \pm \text { S.D. } \\
\text { Med (Min-Max) }\end{array}$ & $\begin{array}{l}\text { Quantitative } \\
\text { Ave. } \pm \text { S.D. } \\
\text { Med (Min-Max) }\end{array}$ & P \\
& $1.000 \pm 0.030$ & $0.997 \pm 0.036$ & $\mathbf{0 . 0 3 2}$ \\
2D: 4D Finger length ratio (Right) & $1.000(0.900-1.090)$ & $0.992(0.900-1.120)$ & 0.285 \\
2D: 4D Finger length ratio (Left) & $1.000 \pm 0.032$ & $0.999 \pm 0.033$ & \\
& $1.006(0.890-1.110)$ & $0.998(0.930-1.110)$ & $0.997 \pm 0.036$ \\
2D: 4D Finger length ratio (Dominant Hand) & $1.004 \pm 0.031$ & $0.993(0.900-1.120)$ & $\mathbf{0 . 0 4 2}$ \\
\hline
\end{tabular}

Table III. The distribution of the finger lengths and ratios according to sex.

\begin{tabular}{|c|c|c|c|}
\hline \multirow{4}{*}{ Variables } & \multicolumn{2}{|c|}{ Groups } & \multirow{4}{*}{$\mathrm{P}$} \\
\hline & Male & Female & \\
\hline & Ave. \pm S.D. & Ave. \pm S.D. & \\
\hline & Med(Min-Max) & Med(Min-Max) & \\
\hline \multirow{2}{*}{ Right Hand $2 \mathrm{n}^{\mathrm{d}}$ Finger Length (mm) } & $72.7 \pm 4.3$ & $67.5 \pm 4.1$ & \multirow{2}{*}{$<0.001$} \\
\hline & $72.3(62.8-84.8)$ & $67.7(56.9-76.7)$ & \\
\hline \multirow{2}{*}{ Left Hand $2 \mathrm{n}^{\mathrm{d}}$ Finger Length $(\mathrm{mm})$} & $73.1 \pm 4.3$ & $67.4 \pm 4.0$ & \multirow{2}{*}{$<0.001$} \\
\hline & $72.7(62.3-86.4)$ & $67.3(57.6-78.4)$ & \\
\hline \multirow{2}{*}{ Right Hand $4 \mathrm{t}^{\mathrm{h}}$ Finger Length (mm) } & $73.2 \pm 4.5$ & $67.1 \pm 4.0$ & \multirow{2}{*}{$<0.001$} \\
\hline & $73.0(59.8-86.8)$ & $67.2(57.1-78.9)$ & \\
\hline \multirow{2}{*}{ Left Hand $4 \mathrm{t}^{\mathrm{h}}$ Finger Length $(\mathrm{mm})$} & $73.3 \pm 4.4$ & $67.1 \pm 3.9$ & \multirow{2}{*}{$<0.001$} \\
\hline & $72.9(60.4-87.2)$ & $67.2(54.4-77.8)$ & \\
\hline \multirow{2}{*}{ 2D: 4D Finger length ratio (Right) } & $0.994 \pm 0.033$ & $1.006 \pm 0.033$ & \multirow{2}{*}{$<0.001$} \\
\hline & $0.991(0.900-1.120)$ & $1.010(0.900-1.090)$ & \\
\hline \multirow{2}{*}{ 2D: 4D Finger length ratio (Left) } & $0.997 \pm 0.031$ & $1.006 \pm 0.034$ & \multirow{2}{*}{$<0.001$} \\
\hline & $0.999(0.900-1.120)$ & $1.006(0.890-1.110)$ & \\
\hline \multirow{2}{*}{ 2D: 4D Finger length ratio (Dominant Hand) } & $0.995 \pm 0.034$ & $1.007 \pm 0.033$ & \multirow{2}{*}{$<0.001$} \\
\hline & $0.993(0.900-1.120)$ & $1.011(0.900-1.090)$ & \\
\hline
\end{tabular}


BALCI, R. S.; AÇIKGÖZ, A. K.; GÖKER, P. \& BOZKIR, M. G. The relationship of finger length ratios (2D:4D) with quantitative, verbal talent and anthropometric parameters Int. J. Morphol., 36(1):310-318, 2018

Table IV. Variable distribution of the male participants for groups.

\begin{tabular}{|c|c|c|c|}
\hline Variables & $\begin{array}{l}\text { Groups } \\
\text { Verbal } \\
\text { Ave. } \pm \text { S.D. } \\
\text { Med (Min-Max) }\end{array}$ & $\begin{array}{l}\text { Quantitative } \\
\text { Ave. } \pm \text { S.D. } \\
\text { Med (Min-Max) }\end{array}$ & $\mathbf{P}$ \\
\hline Age & $\begin{array}{l}20.7 \pm 2.4 \\
20.0(18.0-27.0)\end{array}$ & $\begin{array}{l}20.2 \pm 2.1 \\
20.0(18.0-27.0)\end{array}$ & 0.200 \\
\hline Weight & $\begin{array}{l}77.1 \pm 11.9 \\
76.0(56.0-112.0)\end{array}$ & $\begin{array}{l}77.5 \pm 12.9 \\
78.0(42.0-105.0)\end{array}$ & 0.815 \\
\hline Height & $\begin{array}{l}1.8 \pm 0.1 \\
1.8(1.7-2.0)\end{array}$ & $\begin{array}{l}1.8 \pm 0.1 \\
1.8(1.5-1.9)\end{array}$ & 0.399 \\
\hline Waist Circumference & $\begin{array}{l}85.6 \pm 8.0 \\
85.0(70.0-104.5)\end{array}$ & $\begin{array}{l}88.0 \pm 9.4 \\
88.0(65.0-110.0)\end{array}$ & 0.05 \\
\hline Hip Circumference & $\begin{array}{l}99.2 \pm 7.7 \\
99.0(84.0-118.5)\end{array}$ & $\begin{array}{l}101.3 \pm 8.5 \\
101.0(80.0-122.0)\end{array}$ & 0.05 \\
\hline Neck Circumference & $\begin{array}{l}37.3 \pm 2.1 \\
37.0(32.0-42.0)\end{array}$ & $\begin{array}{l}37.0 \pm 2.2 \\
37.0(30.5-42.0)\end{array}$ & 0.318 \\
\hline Right Hand Length (cm) & $\begin{array}{l}19.2 \pm 0.8 \\
19.2(17.0-21.0)\end{array}$ & $\begin{array}{l}18.8 \pm 1.0 \\
18.8(16.0-21.1)\end{array}$ & 0.002 \\
\hline Left Hand Length (cm) & $\begin{array}{l}19.2 \pm 0.9 \\
19.2(17.2-23.4)\end{array}$ & $\begin{array}{l}18.7 \pm 1.0 \\
18.7(16.4-21.0)\end{array}$ & $<0.001$ \\
\hline Right Hand Width (mm) & $\begin{array}{l}85.3 \pm 3.8 \\
85.1(74.5-94.5)\end{array}$ & $\begin{array}{l}86.3 \pm 4.6 \\
86.8(70.3-101.5)\end{array}$ & 0.087 \\
\hline Left Hand Width (mm) & $\begin{array}{l}85.1 \pm 3.7 \\
84.3(77.0-95.2)\end{array}$ & $\begin{array}{l}85.9 \pm 4.6 \\
86.2(69.8-101.9)\end{array}$ & 0.141 \\
\hline Right Hand $2^{\text {nd }} F_{\text {inger Length }}(\mathrm{mm})$ & $\begin{array}{l}72.3 \pm 3.8 \\
72.1(62.8-82.9)\end{array}$ & $\begin{array}{l}73.0 \pm 4.8 \\
72.7(63.4-84.8)\end{array}$ & 0.240 \\
\hline Left Hand $2^{\text {nd }} F_{\text {inger Length }}(\mathrm{mm})$ & $\begin{array}{l}72.7 \pm 4.0 \\
72.6(62.6-81.7)\end{array}$ & $\begin{array}{l}73.4 \pm 4.6 \\
73.0(62.3-86.4)\end{array}$ & 0.256 \\
\hline Right Hand $4^{\text {th }}$ Finger Length (mm) & $\begin{array}{l}72.6 \pm 3.7 \\
72.5(64.7-84.7)\end{array}$ & $\begin{array}{l}73.7 \pm 5.0 \\
73.7(59.8-86.8)\end{array}$ & 0.097 \\
\hline Left Hand $2^{\text {th }}$ Finger Length $(\mathrm{mm})$ & $\begin{array}{l}72.8 \pm 4.0 \\
72.5(65.4-83.4)\end{array}$ & $\begin{array}{l}73.9 \pm 4.8 \\
73.8(60.4-87.2)\end{array}$ & 0.075 \\
\hline Shoe Size & $\begin{array}{l}42.5 \pm 1.3 \\
42.0(40.0-46.0)\end{array}$ & $\begin{array}{l}42.5 \pm 1.6 \\
42.0(35.0-46.0)\end{array}$ & 0.962 \\
\hline 2D: 4D Finger length ratio (Right) & $\begin{array}{l}0.996 \pm 0.028 \\
0.999(0.900-1.060)\end{array}$ & $\begin{array}{l}0.992 \pm 0.038 \\
0.987(0.920-1.120)\end{array}$ & 0.414 \\
\hline 2D: 4D Finger length ratio (Left) & $\begin{array}{l}1.000 \pm 0.030 \\
1.003(0.900-1.110)\end{array}$ & $\begin{array}{l}0.994 \pm 0.031 \\
0.994(0.930-1.080)\end{array}$ & 0.207 \\
\hline 2D: 4D Finger length ratio (Dominant Hand) & $\begin{array}{l}0.997 \pm 0.028 \\
1.003(0.900-1.060)\end{array}$ & $\begin{array}{l}0.993 \pm 0.038 \\
0.987(0.920-1.120)\end{array}$ & 0.321 \\
\hline Waist-Hip Ratio & $\begin{array}{l}0.864 \pm 0.056 \\
0.860(0.710-1.050)\end{array}$ & $\begin{array}{l}0.869 \pm 0.061 \\
0.870(0.710-1.080)\end{array}$ & 0.571 \\
\hline Body-Mass Index & $\begin{array}{l}24.1 \pm 3.1 \\
23.9(18.2-32.7)\end{array}$ & $\begin{array}{l}24.5 \pm 3.6 \\
24.3(16.6-33.6)\end{array}$ & 0.462 \\
\hline
\end{tabular}

When we evaluated the study groups in terms of height, weight, BMI, 2D:4D length ratios and other anthropometric measurements, it was determined that there were statistically significant differences for sexes $(p<0.05)$. There were no statistically significant differences in terms of hip circumferences and left hand 2D:4D finger length ratios among the verbally weighted concept students.
There were positive correlations between 2D:4D and weight $(r=0.38 ; p<0.001)$, BMI $(r=0.34 ; p=0.01)$ verbally weighted concept male students, and with hip and waist circumferences in quantitatively weighted concept male students. (Table VI). There was a weak and positive correlation between 2D:4D finger length ratios, neck circumferences and the left hand; and this relationship was statistically significant $(\mathrm{r}=0,21 ; \mathrm{p}=0,032$; Table VI). 
Table V. Variable distribution of the female participants for groups.

\begin{tabular}{|c|c|c|c|}
\hline \multirow{4}{*}{ V ariables } & \multicolumn{2}{|l|}{ Groups } & \multirow{4}{*}{$\mathbf{P}$} \\
\hline & Verbal & Quantitative & \\
\hline & Ave. \pm S.D. & Ave. \pm S.D. & \\
\hline & Med (Min-Max) & Med (Min-Max) & \\
\hline \multirow[t]{2}{*}{ Age } & $20.6 \pm 2.9$ & $19.7 \pm 1.8$ & \multirow[b]{2}{*}{0.282} \\
\hline & $20.0(18.0-27.0)$ & $19.0(18.0-27.0)$ & \\
\hline \multirow[t]{2}{*}{ Weight } & $58.7 \pm 9.4$ & $58.8 \pm 9.1$ & \multirow{2}{*}{0.935} \\
\hline & $57.0(43.0-85.0)$ & $57.0(43.0-90.0)$ & \\
\hline \multirow[t]{2}{*}{ Height } & $1.7 \pm 0.1$ & $1.7 \pm 0.1$ & \multirow{2}{*}{0.463} \\
\hline & $1.7(1.5-1.8)$ & $1.7(1.3-1.8)$ & \\
\hline \multirow{2}{*}{ Waist Circumference } & $75.7 \pm 8.4$ & $75.2 \pm 8.2$ & \multirow[b]{2}{*}{0.653} \\
\hline & $75.0(59.5-108.0)$ & $74.1(60.0-110.0)$ & \\
\hline \multirow[t]{2}{*}{ Hip Circumference } & $97.2 \pm 7.7$ & $98.2 \pm 8.1$ & \multirow{2}{*}{0.353} \\
\hline & $96.0(84.0-118.0)$ & $96.0(84.0-126.0)$ & \\
\hline \multirow[t]{2}{*}{ Neck Circumference } & $31.7 \pm 1.5$ & $31.7 \pm 2.0$ & \multirow{2}{*}{0.804} \\
\hline & $32.0(29.0-35.5)$ & $31.5(21.0-38.0)$ & \\
\hline \multirow[t]{2}{*}{ Right Hand Length $(\mathrm{cm})$} & $17.6 \pm 0.8$ & $17.7 \pm 0.7$ & \multirow{2}{*}{0.260} \\
\hline & $17.5(15.0-20.0)$ & $17.7(16.2-19.6)$ & \\
\hline \multirow{2}{*}{ Left Hand Length (cm) } & $17.7 \pm 0.8$ & $17.8 \pm 0.7$ & \multirow{2}{*}{0.305} \\
\hline & $17.7(15.3-20.1)$ & $17.7(16.3-20.0)$ & \\
\hline \multirow[t]{2}{*}{ Right Hand Width (mm) } & $77.6 \pm 3.9$ & $77.1 \pm 4.2$ & \multirow{2}{*}{0.424} \\
\hline & $77.7(62.3-86.4)$ & $76.6(68.4-89.5)$ & \\
\hline \multirow[t]{2}{*}{ Left Hand Width (mm) } & $77.0 \pm 3.8$ & $76.3 \pm 3.9$ & \multirow{2}{*}{0.220} \\
\hline & $77.2(63.5-85.9)$ & $76.3(68.0-89.6)$ & \\
\hline \multirow[t]{2}{*}{ Right Hand $2 \mathrm{n}^{\mathrm{d}}$ Finger Length $(\mathrm{mm})$} & $67.6 \pm 4.0$ & $67.4 \pm 4.2$ & \multirow{2}{*}{0.732} \\
\hline & $68.1(56.9-76.6)$ & $67.6(57.2-76.7)$ & \\
\hline Left Hand $2 \mathrm{n}^{\mathrm{d}}$ Finger Length (mm) & $67.4 \pm 3.8$ & $67.5 \pm 4.2$ & \\
\hline & $67.5(57.6-77.2)$ & $67.2(58.9-78.4)$ & 0.917 \\
\hline Right Hand $4 \mathrm{t}^{\mathrm{h}}$ Finger Length (mm) & $66.8 \pm 3.9$ & $67.4 \pm 4.0$ & \\
\hline & $67.1(57.1-78.9)$ & $67.3(57.4-77.9)$ & 0.367 \\
\hline Left Hand $2 \mathrm{n}^{\mathrm{d}}$ Finger Length (mm) & $67.0 \pm 3.9$ & $67.1 \pm 4.0$ & \\
\hline & $67.2(58.0-77.8)$ & $67.4(54.4-77.6)$ & 0.795 \\
\hline Shoe Size & $37.7 \pm 1.1$ & $37.9 \pm 1.3$ & \\
\hline & $38.0(36.0-42.0)$ & $38.0(35.0-43.0)$ & 0.205 \\
\hline 2D: 4D Finger length ratio (Right) & $1.012 \pm 0.031$ & $1.001 \pm 0.034$ & 0024 \\
\hline & $1.014(0.920-1.090)$ & $1.002(0.900-1.070)$ & 0.024 \\
\hline 2D: 4D Finger length ratio (Left) & $1.007 \pm 0.033$ & $1.005 \pm 0.035$ & \\
\hline & $1.009(0.890-1.070)$ & $1.005(0.940-1.110)$ & 0.160 \\
\hline 2D: 4D Finger length ratio (Dominant Hand) & $1.012 \pm 0.032$ & $1.002 \pm 0.034$ & 0.050 \\
\hline & $1.014(0.920-1.090)$ & $1.004(0.900-1.070)$ & 0.050 \\
\hline Waist-Hip Ratio & $0.779 \pm 0.059$ & $0.765 \pm 0.045$ & \\
\hline & $0.782(0.630-0.930)$ & $0.758(0.660-0.940)$ & 0.058 \\
\hline Body-Mass Index & $21.3 \pm 3.0$ & $21.6 \pm 3.5$ & \\
\hline & $21.0(15.2-29.4)$ & $20.9(16.5-35.0)$ & 0.550 \\
\hline
\end{tabular}

There was no statistically significant correlation between anthropometric measurements and 2D:4D ratios among the quantitatively weighted concept female students; and there was a positive correlation between 2D:4D finger length ratios and waist circumferences in verbally weighted concept female students $(r=0.24$, $\mathrm{p}=0.018$; Table VII).

\section{DISCUSSION}

This study revealed the relationship between 2D:4D ratios and quantitative-verbal intelligences, and also showed the association between these ratios and several anthropometric measurements between males and females. 

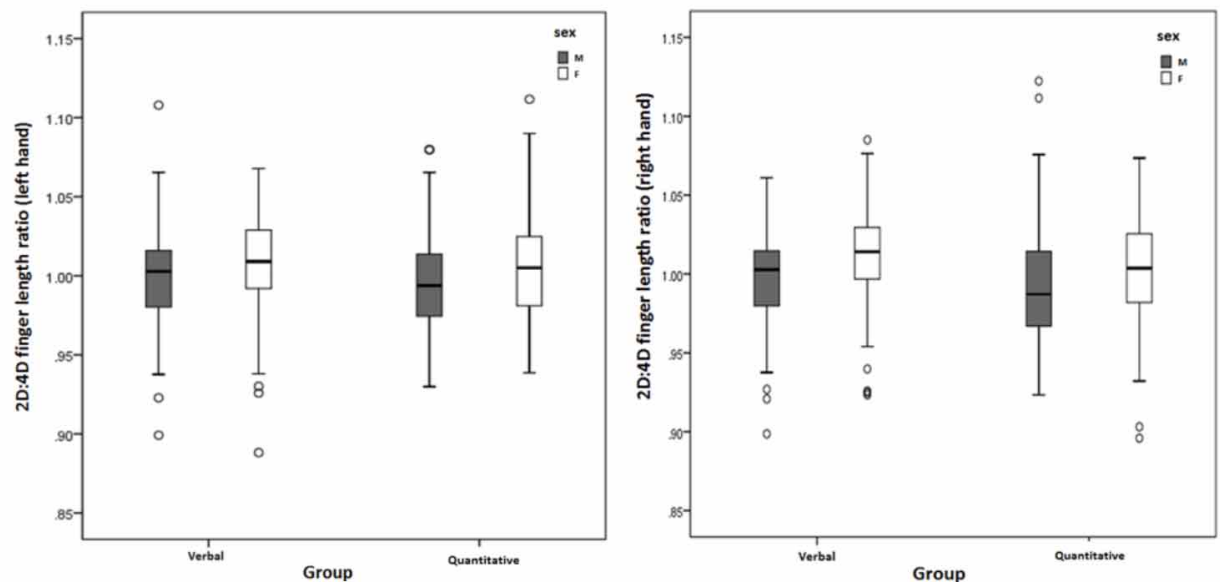

Fig. 2. Boxplot graphics of gender and group differences for right and left hands in terms of 2D:4D ratios.

Table VI. The correlation of 2D:4D finger ratio with anthropometric data for males.

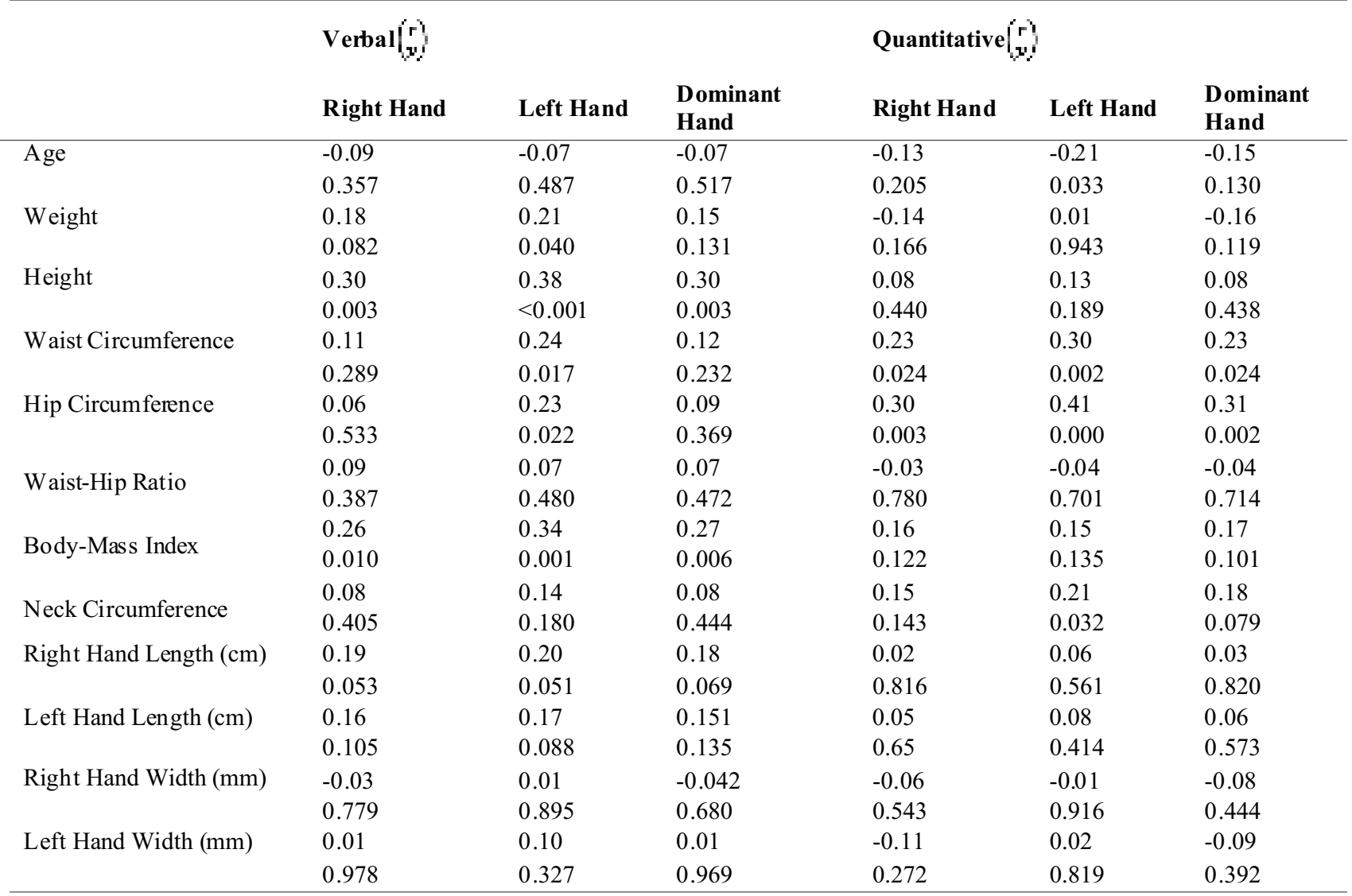

In previous studies, it was reported that 2D:4D ratios, which give very important information about personal characteristics and abilities, have relations with sex-related hormonal levels (Luxen \& Buunk, 2005). It was suggested that while prenatal testosterone level decelerates the development of the left hemisphere, it accelerates the developments of the same regions on the right side. And they also claimed that since right the hemisphere was 
Table VII. The correlation of 2D: 4D finger ratio with anthropometric data for females.

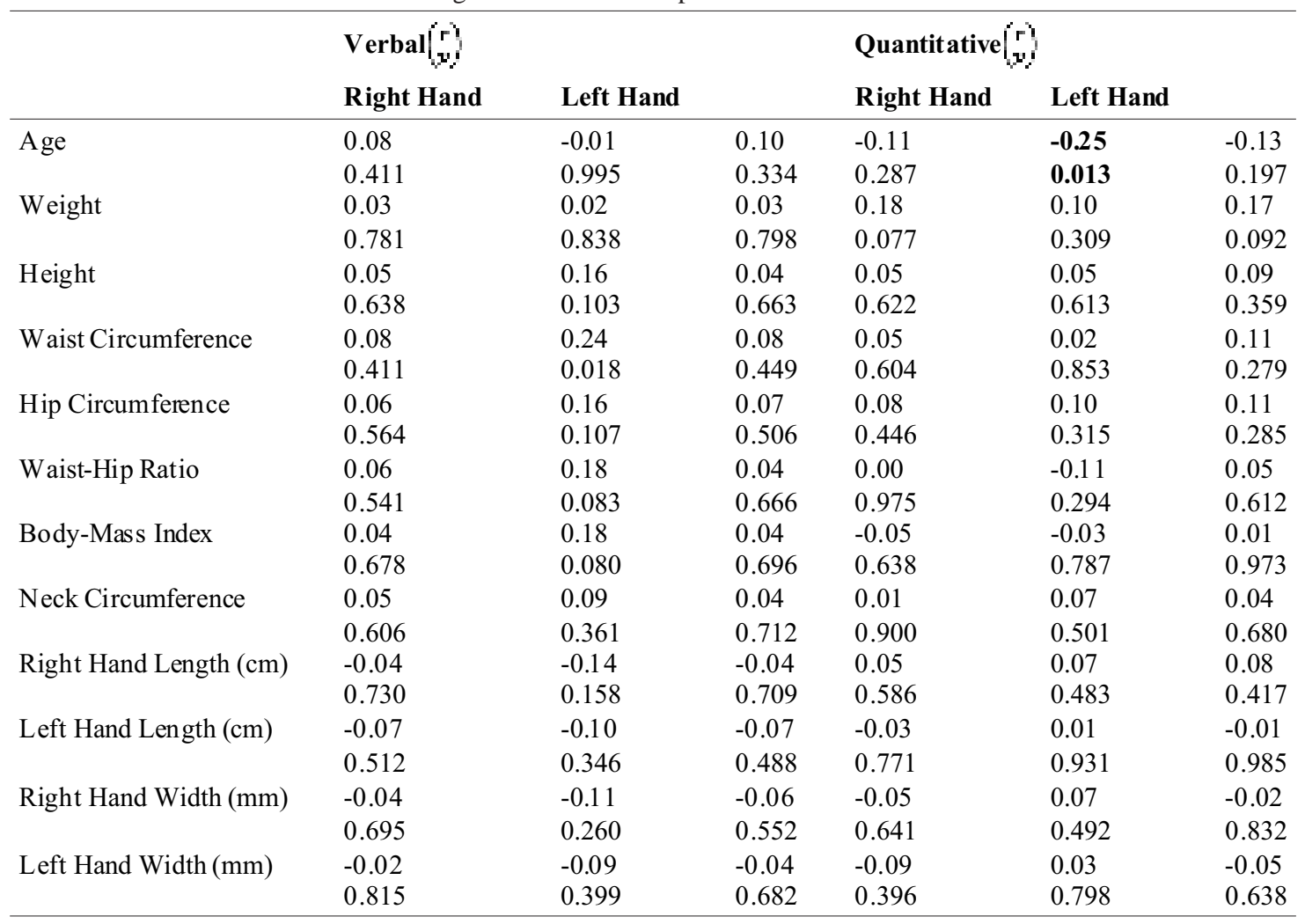

affected, the mathematical and visual talents were developed (Galaburda \& Eidelberg, 1982). And they also claimed that high testosterone levels might cause a tendency for depression by affecting brain development (Manning, 2002). Manning et al. (1998) reported that the second and fourth finger lengths were under the influence of testosterone/ oestrogen hormone levels during the prenatal period (Manning et al., 1998). It has been concluded that testosterone hormone secretion increases the development of the brain in quantitative talent regions, while oestrogen hormone secretion increases the development of verbal talent areas, according to the study performed in England (McCarthy, 2008).

It was reported that the $2 \mathrm{D}: 4 \mathrm{D}$ finger length ratios were found higher in females compared to males in some studies (Manning et al., 2000; Lippa, 2003). Moreover, it was indicated that sex differences were more obviously on the right side (Lippa). However, in some researches, it was established that there were no significant differences between 2D:4D ratios for both sexes (Austin et al., 2002; Benderlioglu \& Nelson, 2004). In our study, there were significant differences in terms of 2D:4D ratios between males and females for right, left and dominant hands $(\mathrm{p}<0.05)$. Additionally, the results of this study showed that the 2D:4D ratios were lower in males than in females and these differences were found to be statistically significant $(p<0.05)$. Furthermore, there were no differences between the male students from verbal and quantitative programmes, whereas there were significant differences on the right and dominant hands among females for 2D:4D finger ratios. On the other hand, the results of this paper showed that there were no significant differences for left hands. According to Tanner's investigation, it was reported that the right side of the body has more sexual dimorphism (Tanner, 1990). In other words, the right side of the body is more sensitive to the testosterone hormone. This could be the explanation of why there was no difference in the left hand in our study. When we analysed the literature findings about the association between 2D:4D finger length ratios and quantitative talents in Dutch individuals, it was estimated that there were significant differences for the right hand while there were no significant differences for the left hand (Luxen \& Buunk). This result supports our study results. According to similar studies focused on this ratio on different populations, our ratios are higher than those reported for South African population, and closer to those reported for England and Spain (Manning et al., 2014). This could be the result of some factors like environmental and genetic variables. 
The distribution of the body adipose tissue was influenced by sexual hormone levels in males and females (Evans et al. 1983; Björntorp, 1991). The oestrogen levels increase the adipose tissue especially around hip and thigh in women (Garn et al., 1975). And it was shown in previous studies that there was an increasing adipose tissue around abdominal, shoulder and neck region as a consequence of high level testosterone in men (Vague et al., 1974). In addition, Manning \& Taylor (2001) reported that there were high risks for myocardial infarction among males, which have low 2D:4D ratios; and they suggested that these ratios could be used to determine the testosterone/oestrogen hormone levels (Manning \& Taylor; Fink et al., 2006). Considering these correlations, it can be concluded that the ratios between finger lengths may be useful for the diagnosis of a possible heart attack. A study which investigated the relationship between 2D:4D ratios and anthropometric measurements, it was reported that there was a significant positive correlation between 2D:4D ratios and neck circumferences. The results of this study are similar to our study results in same terms.

In our investigation, the correlation between 2D:4D ratios and anthropometric measurements was analysed. The results of this study showed that there is a correlation between weight, height and both hands. It was also determined that there are positive correlations among left hand, waist and hip circumferences in verbally talented male participants. Moreover, there was a positive correlation between waist, hip circumferences and left hands and neck circumferences in quantitatively talented male participants $(p<0.05)$. On the other hand, while there was a positive correlation with left hand and waist circumference in verbally talented female participants, there was no significant correlation in quantitatively talented female participants $(p<0.05)$. And there were statistically significant differences between males and females in terms of anthropometric measurements, anatomical variations and sexual dimorphism. Furthermore, hip and waist circumferences were found higher in our quantitatively talented participants than verbally talented participants in both sexes (Tables III and IV). However, there were no significant differences between hip circumferences and left hand 2D:4D ratios. We believe that the difference of hip circumferences is not significant, which indicates that oestrogen causes increasing adipose tissue in these region in women. The data obtained from this study showed that there is a significant correlation between 2D:4D ratios and quantitative-verbal talents in females whereas there is no correlation in male participants. These results were found to be statistically significant $(\mathrm{p}<0.05)$. Moreover, there was a significant correlation between 2D:4D ratios and anthropometric values in both sexes.
In conclusion, we believe that the data obtained in this paper, especially 2D:4D ratios among females, may be useful for the identification of the tendency of quantitative and verbal talents. Therefore, we also believe that these results may guide individuals for their educational decisions, selection of verbal and quantitative fields, and help for their career plans.

BALCI, R. S.; AÇIKGÖZ, A. K.; GÖKER, P. \& BOZKIR, M. G.La relación de las proporciones de la longitud del dedo (2D:4D) con el parámetro Cuantitativo, Talento verbal y parámetros antropométricos. Int. J. Morphol., 36(1):310-318, 2018.

RESUMEN: El objetivo de este estudio consistió en investigar la relación entre índices de longitud del dedo (2D:4D) (es decir, la relación de la longitud del segundo dedo a la cuarta longitud del dedo) de los estudiantes de campos ponderados verbales y cuantitativos, para determinar la correlación de estas proporciones con algunas medidas antropométricas. Para este propósito, se consideraron las siguientes mediciones: longitud de la mano, ancho de la mano, circunferencia del segundo y cuarto dedo y circunferencia de cintura, cadera y cuello. Se examinaron 398 estudiantes (199 mujeres, 199 hombres) de 17-25 años de edad, usando pinzas milimétricas y cinta métrica estándar no elástica. También se tomaron datos demográficos. Además, se calcularon las proporciones de índice de masa corporal (IMC) y 2D:4D del grupo de estudio. Cuando investigamos las proporciones 2D:4D para manos derechas, izquierdas y dominantes entre individuos talentosos verbales y cuantitativos en mujeres, hubo diferencias estadísticamente significativas para la mano derecha y dominante $(p=0,032, p=0,042$, respectivamente). Por otro lado, no hubo diferencia para la mano izquierda en las mujeres ( $\mathrm{p}>0.05)$. Además, hubo correlaciones positivas con 2D:4D y peso $(r=0,38, p<0,001)$, IMC $(r=$ $0,34, p=0,01)$ de los hombres en el campo verbalmente ponderado y con circunferencias de cadera y cintura en hombres en campo ponderado cuantitativamente $(r=0,30, p=0,002 ; r=$ $0.41, \mathrm{p}<0,001)$. En los hombres, en campos cuantitativamente ponderados, hubo una correlación débil y positiva en $2 \mathrm{D}$, relaciones de longitud de dedo 4D y circunferencias de cuello en la mano izquierda, y esta relación fue estadísticamente significativa $(\mathrm{r}=0,21, \mathrm{p}=0,032)$. También, no hubo correlaciones estadísticamente significativas entre las medidas antropométricas y las proporciones 2D:4D entre las estudiantes en el campo cuantitativamente ponderado. Mientras que hubo correlaciones positivas con 2D:4D, índices de longitud del dedo y circunferencia de la cintura en las mujeres en el campo ponderado verbalmente $(r=0,24, p=0,018)$. Creemos que los datos obtenidos en este estudio serán una guía para los objetivos de planificación de carrera de las personas de acuerdo con sus talentos cuantitativos y verbales.

PALABRAS CLAVE: Indices de longitud del dedo; Talento cuantitativo; Talento verbal. 


\section{REFERENCES}

Austin, E. J.; Manning, J. T.; McInroy, K. \& Mathews, E. A preliminary investigation of the associations between personality, cognitive ability and digit ratio. Personal. Individ. Differ, 33(7):1115-24, 2002.

Benderloglu, Z. \& Nelson, R. J. Digit length ratios predict reactive aggression in women, but not in men. Horm. Behav., 46(5):558-64, 2004.

Björntorp, P. Adipose tissue distribution and function. Int. J. Obes. (Lond.), 15 Suppl. 2:67-81, 1991.

Çelik, A.; Aksu, F.; Tunar, M.; Dasdan Ada, E. N. \& Topaçoglu, H. Master atletlerin fiziksel performans düzeylerinin eldeki parmak oranlarıyla ilis skisi. DEÜ Tip Fakültesi Dergisi, 24:5-10, 2010.

Evans, D. J.; Hoffmann, R. G.; Kalkhoff, R. K. \& Kissebah, A. H. Relationship of androgenic activity to body fat topography, fat cell morphology, and metabolic aberrations in premenopausal women. $J$. Clin. Endocrinol. Metab., 57(2):304-10, 1983.

Fink, B.; Manning, J. T. \& Neave, N. Second to fourth digit ratio and the 'big five' personality factors. Personal. Individ. Differ., 37:495-503, 2004.

Fink, B.; Manning, J. T. \& Neave, N. The $2^{\text {nd }}-4^{\text {th }}$ digit ratio (2D:4D) and neck circumference: implications for risk factors in coronary heart disease. Int. J. Obes. (Lond.), 30(4):711-4, 2006.

Fowkes, F. G.; Leng, G. C.; Donnan, P. T.; Deary, I. J.; Riemersma, R. A. \& Housley, E. Serum cholesterol, triglycerides, and aggression in the general population. Lancet, 340(8826):995-8, 1992.

Galaburda, A. M. \& Eidelberg, D. Symmetry and asymmetry in the human posterior thalamus. II. Thalamic lesions in a case of developmental dyslexia. Arch. Neurol., 39(6):333-6, 1982.

Gardner, H. \& Hatch, T. Multiple intelligences go to school: Educational implications of the theory of multiple intelligences. Am. Educ. Res. Assoc., 18(8):4-10, 1989.

Garn, S. M.; Burdi, A. R.; Babler, W. J. \& Stinson, S. Early prenatal attainment of adult metacarpal-phalangeal rankings and proportions. Am. J. Phys. Anthropol., 43(3):327-32, 1975.

Lippa, R. A. Are 2D:4D finger-length ratios related to sexual orientation? Yes for men, no for women. J. Pers. Soc. Psychol., 85(1):179-88, 2003.

Luxen, M. F. \& Buunk, B. P. Second-to-fourth digit ratio related to Verbal and Numerical Intelligence and the Big Five. Personal. Individ. Differ., 39(5):959-66, 2005.

Manning, J. T. \& Taylor, R. P. Second to fourth digit ratio and male ability in sport: implications for sexual selection in humans. Evol. Hum. Behav, 22(1):61-9, 2001.

Manning, J. T. Digit Ratio: A Pointer to Fertility, Behavior and Health. New Brunswick, Rutgers University Press, 2002.

Manning, J. T.; Barley, L.; Walton, J.; Lewis-Jones, D. I.; Trivers, R. L.; Singh, D.; Thornhill, R.; Rhode, P.; Bereczkei, T.; Henzi. P.; Soler, M. \& Szwed, A. The 2nd:4th digit ratio, sexual dimorphism, population differences, and reproductive success. evidence for sexually antagonistic genes? Evol. Hum. Behav, 21(3):163-83, 2000.

Manning, J. T.; Bundred, P.E.; Newton, D. J. \& Flanagan, B. F. The second to fourth digit ratio and variation in the androgen receptor gene. Evol. Hum. Behav., 24(6):399-405, 2003.

Manning, J. T.; Fink, B. \& Trivers, R. Digit ratio (2D:4D) and gender inequalities across nations. Evol. Psychol., 12(4):757-68, 2014.

Manning, J. T.; Scott, D.; Wilson, J. \& Lewis-Jones, D. I. The ratio of 2nd to 4th digit length: a predictor of sperm numbers and concentrations of testosterone, luteinizing hormone and oestrogen. Hum. Reprod., 13(11):3000-4, 1998.

Manning, J. T.; Wood, S.; Vang, E.; Walton, J.; Bundred, P. E.; van Heyningen, C. \& Lewis-Jones, D. I. Second to fourth digit ratio (2D:4D) and testosterone in men. Asian J. Androl., 6(3):211-6, 2004.

McCarthy, M. M. Estradiol and the developing brain. Physiol. Rev., 88(1):91-124, 2008.
McGue, M. \& Bouchard, T. J. Jr. Genetic and environmental influences on human behavioral differences. Annu. Rev. Neurosci, 21:1-24, 1998.

Tanner, J. M. Foetus into Man: Physical Growth from Conception to Maturity. Cambridge, Harvard University Press, 1990.

Trivers, R.; Manning, J. \& Jacobson, A. A longitudinal study of digit ratio (2D:4D) and other finger ratios in Jamaican children. Horm. Behav., 49(2):150-6, 2006.

Vague, J.; Rubin, P.; Jubelin, J.; Lam-Van, G.; Aubert, F.; Wassermann, A .M. \& Fondarai, J. Regulation of the Adipose Mass: Histometric and Anthropometric Aspects. In: Vague, J. \& Boyer, J. (Eds.). Regulation of the Adipose Tissue Mass. Amsterdam, Excerpta Medica, 1974. pp.296-310.

\section{Corresponding author: \\ Prof. Dr. Pinar Göker, M.D. \\ Cukurova University \\ Faculty of Medicine \\ Department of Anatomy \\ 01330 Adana \\ TURKEY}

\section{E-mail: pkarakas@cu.edu.tr}

Received : 15-05-2017

Accepted : 11-09-2017 